\title{
Dynamic hyperinflation and intrinsic positive end-expiratory pressure in ARDS patients
}

\author{
Silvia Coppola ${ }^{1}$, Alessio Caccioppola ${ }^{2}$, Sara Froio ${ }^{1}$, Erica Ferrari ${ }^{2}$, Miriam Gotti ${ }^{1}$, Paolo Formenti ${ }^{1}$ and
} Davide Chiumello $0^{1,2,3,4^{*}}$ (D)

\begin{abstract}
Background: In ARDS patients, changes in respiratory mechanical properties and ventilatory settings can cause incomplete lung deflation at end-expiration. Both can promote dynamic hyperinflation and intrinsic positive endexpiratory pressure (PEEP). The aim of this study was to investigate, in a large population of ARDS patients, the presence of intrinsic PEEP, possible associated factors (patients' characteristics and ventilator settings), and the effects of two different external PEEP levels on the intrinsic PEEP.

Methods: We made a secondary analysis of published data. Patients were ventilated with a tidal volume of 6-8 $\mathrm{mL} / \mathrm{kg}$ of predicted body weight, sedated, and paralyzed. After a recruitment maneuver, a PEEP trial was run at 5 and $15 \mathrm{cmH}_{2} \mathrm{O}$, and partitioned mechanics measurements were collected after 20 min of stabilization. Lung computed tomography scans were taken at 5 and $45 \mathrm{cmH}_{2} \mathrm{O}$. Patients were classified into two groups according to whether or not they had intrinsic PEEP at the end of an expiratory pause.

Results: We enrolled 217 sedated, paralyzed patients: 87 (40\%) had intrinsic PEEP with a median of 1.1 [1.0-2.3] $\mathrm{CmH}_{2} \mathrm{O}$ at $5 \mathrm{cmH}_{2} \mathrm{O}$ of PEEP. The intrinsic PEEP significantly decreased with higher PEEP (1.1 [1.0-2.3] vs 0.6 [0.0-1.0] $\left.\mathrm{CmH}_{2} \mathrm{O} ; p<0.001\right)$. The applied tidal volume was significantly lower (480 [430-540] vs 520 [445-600] $\mathrm{mL}$ at $5 \mathrm{cmH}_{2} \mathrm{O}$ of PEEP; 480 [430-540] vs 510 [430-590] $\mathrm{mL}$ at $15 \mathrm{cmH}_{2} \mathrm{O}$ ) in patients with intrinsic PEEP, while the respiratory rate was significantly higher (18 [15-20] vs 15 [13-19] bpm at $5 \mathrm{cmH}_{2} \mathrm{O}$ of PEEP; 18 [15-20] vs 15 [13-19] bpm at $15 \mathrm{cmH}_{2} \mathrm{O}$ ). At both PEEP levels, the total airway resistance and compliance of the respiratory system were not different in patients with and without intrinsic PEEP. The total lung gas volume and lung recruitability were also not different between patients with and without intrinsic PEEP (respectively 961 [701-1535] vs 973 [659-1433] $\mathrm{mL}$ and 15 [0-32] \% vs 22 [0-36] \%).
\end{abstract}

Conclusions: In sedated, paralyzed ARDS patients without a known obstructive disease, the amount of intrinsic PEEP during lung-protective ventilation is negligible and does not influence respiratory mechanical properties.

Keywords: Acute respiratory distress syndrome, Intrinsic positive end-expiratory pressure, Respiratory mechanics, Gas exchange

\footnotetext{
* Correspondence: chiumello@libero.it

${ }^{1}$ Department of Anesthesia and Intensive Care, ASST Santi Paolo e Carlo, San

Paolo University Hospital, Milan, Italy

${ }^{2}$ Department of Health Sciences, University of Milan, Milan, Italy

Full list of author information is available at the end of the article
}

(c) The Author(s). 2019 Open Access This article is distributed under the terms of the Creative Commons Attribution 4.0 International License (http://creativecommons.org/licenses/by/4.0/), which permits unrestricted use, distribution, and reproduction in any medium, provided you give appropriate credit to the original author(s) and the source, provide a link to the Creative Commons license, and indicate if changes were made. The Creative Commons Public Domain Dedication waiver (http://creativecommons.org/publicdomain/zero/1.0/) applies to the data made available in this article, unless otherwise stated. 


\section{Background}

In patients with acute respiratory failure, changes in respiratory mechanical properties (compliance and resistance) can cause incomplete deflation of the respiratory system at end-expiration, promoting dynamic hyperinflation [1,2]. When this happens, the alveolar pressure at end-expiration can exceed atmospheric pressure or the positive end-expiratory pressure (PEEP) applied during mechanical ventilation, generating an occult or intrinsic PEEP $[3,4]$. Thus, in mechanically ventilated patients, the total PEEP is the sum of the external PEEP provided by the ventilator and the intrinsic PEEP when present. Hyperinflation and intrinsic PEEP have been reported in up to $90 \%$ of the patients with acute exacerbation of chronic obstructive pulmonary disease (COPD). This is due to dynamic airway compression with an increase in lung compliance that can limit expiratory flow [5-7]. This limitation is seen when, at a given lung volume, expiratory flow cannot be increased by raising the expiratory driving pressure, which is the difference between the plateau and expiratory pressures at the Y-piece $[8,9]$.

In patients with acute respiratory distress syndrome (ARDS), intrinsic PEEP has been mainly reported only in the first days of mechanical ventilation with lower levels than in COPD patients [10]. In one of the first descriptions, Rossi et al. reported intrinsic PEEP in 10 of 14 patients, with values from 0.5 to $7.5 \mathrm{cmH}_{2} \mathrm{O}$ [4]. Furthermore, when intrinsic PEEP is not taken into consideration, respiratory compliance can be significantly underestimated by about 48\% [4]. Expiratory flow limitation is the main cause of intrinsic PEEP in $80-90 \%$ of ARDS patients $[5,11,12]$. The severity of the limitation closely relates with intrinsic PEEP and diminishes with the application of an external PEEP $[11,12]$.

In addition to the expiratory flow limitation, which mainly occurs during active breathing, in sedated ARDS patients, other mechanisms can be involved in the generation of intrinsic PEEP, such as mechanical ventilation per se or the ventilatory setting [13]. In ARDS patients, lung-protective ventilation with a low tidal volume and moderate/high respiratory rate to avoid or limit respiratory acidosis has been reported to promote the development of intrinsic PEEP and dynamic hyperinflation [14-16].

In up to $20 \%$ of ARDS patients, an airway closure (defined as the lack of communication between the proximal airways and alveoli) can be another factor responsible for the development of intrinsic PEEP [17-19].

The aim of this study was to evaluate, in a large population of mechanically ventilated ARDS patients, the presence and amount of intrinsic PEEP, any associated factors (patients' characteristics and ventilator settings), and the effects of two different levels of external PEEP on intrinsic PEEP.

\section{Methods}

\section{Study population}

ARDS patients enrolled in seven previous studies [20-26] were analyzed. The institutional review board of each hospital approved each study, and written consent was obtained according to the regulations applicable in each institution.

Patients were retrospectively classified according to the Berlin criteria [27] for five studies [20, 22-25] and according to the American European Consensus Conference for two studies [21, 26]. The median time between diagnosis and enrollment was 2 days [1-5].

Exclusion criteria were age less than 16 years, pregnancy, asthma or chronic obstructive pulmonary disease (COPD) reported in the patient's medical history, and hemodynamic instability.

Patients were classified according to the presence or absence of intrinsic PEEP at the end of an expiratory pause (3-5s) when any total PEEP higher than an external PEEP of $5 \mathrm{cmH}_{2} \mathrm{O}$ was detected.

\section{Study protocol}

Patients were supine, orally intubated, sedated, and paralyzed, with a bolus of vecuronium $[23,24,26]$ or rocuronium every $20 \mathrm{~min}$ [22] for the duration of the study, and thereafter according to clinical judgment. Patients were mechanically ventilated in volume control mode, and all measurements were recorded in volume control mode.

The tidal volume was set at $6-8 \mathrm{~mL} / \mathrm{kg}$ of predicted body weight with a respiratory rate to maintain an arterial $\mathrm{pH}$ of $7.30-7.45$. The inspiratory time was set at $33 \%$ of the total respiratory time using a square-wave inspiratory flow.

A recruitment maneuver was done to standardize lung volume history, in pressure-controlled ventilation at PEEP $5 \mathrm{cmH}_{2} \mathrm{O}$, with a plateau pressure of $45 \mathrm{cmH}_{2} \mathrm{O}$, I: E 1:1, and respiratory rate 10 breaths/min for $2 \mathrm{~min}$ [18]. Then, from a minimum of $20 \mathrm{~min}$ to a maximum of 60 min after the recruitment maneuver, the same tidal volume, respiratory rate, and oxygen fraction were applied and a PEEP trial (at PEEP 5 and $15 \mathrm{cmH}_{2} \mathrm{O}$ ) was done. At both PEEP levels, respiratory mechanics were measured, and blood gas analyses were done after $20 \mathrm{~min}$. The external PEEP and total PEEP were measured at the end of the expiration of a regular breath and at the end of an expiratory pause (3-5 s). Intrinsic PEEP was defined as the total PEEP minus the external PEEP $[4,28]$.

\section{Respiratory mechanics measurements}

Respiratory mechanics data were acquired with dedicated transducers. Flow at airway opening was measured with a heated pneumotachograph (Fleish 2, Lausanne, Switzerland). Airway pressure was measured proximally to the endotracheal tube with a pressure transducer (MPX 2010 DP. Motorola, Solna, Sweden). In all patients, a heat 
and moisture exchanger (DARTM, Convidien ${ }^{\mathrm{Tx}}$, AdultPediatric) was placed between the endotracheal tube and the pneumotacograph.

A radio-opaque esophageal balloon (SmathCath Bicore, USA) was positioned in the lower third of the esophagus $35-40 \mathrm{~cm}$ from the nose. Esophageal pressure was measured by connecting the balloon, inflated with $1.0-1.5 \mathrm{~mL}$ of air, to a pressure transducer [29]. All traces were sampled at $100 \mathrm{~Hz}$ and processed on a dedicated data acquisition system (Colligo and Computo).

During inspiratory and expiratory pauses, the static airway and esophageal pressures were measured. The resulting physiological variables were computed according to standard formulas (see Additional file 1).

\section{Gas exchange}

Arterial blood gases were analyzed. The alveolar dead space was computed measuring the end-tidal expired partial pressure of carbon dioxide with a $\mathrm{CO}_{2} \mathrm{SMO}$ monitor; the physiological dead space was computed according to the Enghoff modification of Bohr's equation, measuring the mixed expired partial pressure of carbon dioxide with a $\mathrm{CO}_{2} \mathrm{SMO}$ monitor (Novametrix, Wallingford, UK) [30]. (see Additional file 1).

\section{Computer tomography scans}

After the PEEP trial, patients were moved to the radiology department and two whole-lung computer tomography (CT) scans were taken, after a recruitment maneuver. During an end-expiratory pause at $5 \mathrm{~cm} \mathrm{H}_{2} \mathrm{O}$ of PEEP and an inspiratory pause at $45 \mathrm{cmH}_{2} \mathrm{O}$ of plateau pressure. Lung CT scans were taken using the following parameters: $110 \mathrm{mAs}$, tube voltage $120 \mathrm{kV}$, rotation time $0.5 \mathrm{~s}$, collimation $128 \times 0.6 \mathrm{~mm}$, reconstruction matrix $512 \times 512$. In each CT slice, lung profiles were outlined manually and analyzed with a dedicated software package (Soft-E-Film, www.softefilm.eu). The total lung gas volume, weights, and amounts of the different compartments (not inflated, poorly inflated, well inflated, and over-inflated) were calculated as previously described [31].

Lung recruitability was computed as the ratio of the difference between not-inflated tissue at $5 \mathrm{cmH}_{2} \mathrm{O}$ of PEEP and that at $45 \mathrm{cmH}_{2} \mathrm{O}$ of plateau pressure to the total lung tissue at $5 \mathrm{cmH}_{2} \mathrm{O}$ of PEEP [21].

\section{Statistical analysis}

Data were not normally distributed, and non-parametric methods were applied. When not otherwise specified, categorical data are reported as frequencies and percentages, while continuous data are presented as medians [interquartile range]. Baseline characteristics of the patients with and without intrinsic PEEP were compared by the Mann-Whitney rank sum test.

Two-way repeated measures analysis of variance (ANOVA) followed by all pairwise multiple comparison procedures (Holm-Sidak method) was applied to investigate the effects of intrinsic and external PEEP on respiratory mechanics, CT data, and gas exchanges.

$p$ values 0.05 or less were considered statistically significant. The statistical analysis was done with SigmaPlot 11.0 (Systat Software, San Jose, CA) and Prism 6.00 software (GraphPad, San Diego, CA, USA).

\section{Results}

A total of 217 patients were studied in the early phase of ARDS, within 3 days [2-6] of onset. Their baseline clinical characteristics are reported in Table 1. Eighty-seven patients (40\%) had intrinsic PEEP with a median of 1.1 [1.0-2.3] $\mathrm{cmH}_{2} \mathrm{O}$ at $5 \mathrm{cmH}_{2} \mathrm{O}$ of PEEP. Among these 87, 3 (3\%) had an intrinsic PEEP lower than $1 \mathrm{cmH}_{2} \mathrm{O}, 71$ (82\%) between 1 and $3 \mathrm{cmH}_{2} \mathrm{O}$, and 13 (15\%) higher than $3 \mathrm{cmH}_{2} \mathrm{O}$. Patients with intrinsic PEEP had a significantly higher body mass index and arterial carbon dioxide than those without intrinsic PEEP. The respiratory rate and minute ventilation were significantly higher (18 [16-21] vs 15 [12-20] breaths/min; 9.0 [7.6-11.6] vs $8.2[6.8-9.7] \mathrm{L} / \mathrm{min})$, while tidal volume was lower in patients with intrinsic PEEP (480 [420-550] vs 500 [450-600] mL) (Table 1; see Additional file 1: Figure S1).

\section{Respiratory mechanics at different PEEP}

The intrinsic PEEP significantly on raising PEEP from 5 to $15 \mathrm{cmH}_{2} \mathrm{O}\left(1.1[1.0-2.3]\right.$ vs $\left.0.6[0.0-1.0] \mathrm{cmH}_{2} \mathrm{O} ; p<0.001\right)$.

Among these patients with intrinsic PEEP at $5 \mathrm{cmH}_{2} \mathrm{O}$, when external PEEP was raised, $89 \%$ presented a decrease in intrinsic PEEP with a median of $-1[-2.00$ to $-0.96], 7 \%$ showed an increase $\left(0.6[0.17-1.25] \mathrm{cmH}_{2} \mathrm{O}\right)$, and only $4 \%$ had no change. Eight of the patients without intrinsic PEEP (6\%) developed a small amount of intrinsic PEEP while the remaining 94\% did not (Fig. 1).

At both 5 and $15 \mathrm{cmH}_{2} \mathrm{O}$ of PEEP, the applied tidal volume was significantly lower in patients with intrinsic PEEP (480 [430-540] vs 520 [445-600] $\mathrm{mL}$ at $5 \mathrm{cmH}_{2} \mathrm{O}$; 480 [430-540] vs 510 [430-590] at $\left.15 \mathrm{cmH}_{2} \mathrm{O}\right)$ while the respiratory rate was significantly higher (18 [15-20] vs 15 [13-19] bpm at $5 \mathrm{cmH}_{2} \mathrm{O} ; 18$ [15-20] vs 15 [1319] bpm at $15 \mathrm{cmH}_{2} \mathrm{O}$ ) (Table 2).

Lung compliance was significantly higher in patients with intrinsic PEEP $(p=0.004)$ while the airway plateau pressure and driving pressure were not different (Table 2 and Additional file 1: Table S1).

Expiratory time was lower than 3 time constants in 56 patients $(26 \%)$ out of the whole population; this happened in $30(34 \%)$ patients with and $26(20 \%)$ without intrinsic PEEP. The expiratory time was lower in patients with intrinsic PEEP at both PEEP levels while total airway resistance and compliance of the respiratory system were not different in patients with and without intrinsic PEEP (Table 2). 
Table 1 Baseline characteristics of the study population in relation to the presence of intrinsic PEEP

\begin{tabular}{|c|c|c|c|c|}
\hline & Total population $(n=217)$ & Patients with intrinsic PEEP $(n=87)$ & Patients without intrinsic PEEP $(n=130)$ & $p$ \\
\hline Age (yr) & $61[48-73]$ & $60[48-61]$ & $62[48-73]$ & 0.69 \\
\hline Female \% (n) & $32(69)$ & $28(24)$ & $35(45)$ & 0.30 \\
\hline Height (cm) & $170[162-177]$ & $170[163-180]$ & $170[162-175]$ & 0.34 \\
\hline $\mathrm{BMI}\left(\mathrm{kg} / \mathrm{m}^{2}\right)$ & 25 [22-29] & $27[23-29]$ & $24[22-28]$ & 0.004 \\
\hline Intensive care unit stay (days) & 18 [18-26] & 19 [10-28] & $17[10-25]$ & 0.58 \\
\hline SAPS I| score & 40 [32-53] & $41[33-50]$ & $40[32-53]$ & 0.82 \\
\hline Hospital mortality \% ( $n)$ & $46(99)$ & $46(47)$ & $40(52)$ & 0.05 \\
\hline $\mathrm{PaO}_{2} / \mathrm{FiO}_{2}$ & $173[132-224]$ & 159 [119-193] & 188 [142-225] & 0.008 \\
\hline $\mathrm{PaCO}_{2}(\mathrm{mmHg})$ & $42[37-49]$ & $44[39-51$ & $41[36-48]$ & 0.005 \\
\hline ARDS category \% ( $n)$ & & & & 0.09 \\
\hline • Mild & $18(40)$ & $16(14)$ & $15(20)$ & \\
\hline - Moderate & $62(135)$ & $58(50)$ & $65(85)$ & \\
\hline - Severe & $20(42)$ & $26(23)$ & $20(25)$ & \\
\hline Cause of ARDS \% (n) & & & & 0.78 \\
\hline - Pulmonary & $57(123)$ & $55(48)$ & $58(75)$ & \\
\hline - Extrapulmonary & $43(94)$ & $45(39)$ & $42(55)$ & \\
\hline Respiratory rate (breath/min) & 16 [14-20] & 18 [16-21] & 15 [12-20] & $<0.0001$ \\
\hline Tidal volume $(\mathrm{mL})$ & $500[430-586]$ & $480[420-550]$ & $500[450-600]$ & 0.03 \\
\hline $\begin{array}{l}\text { Tidal volume/body } \\
\text { weight }(\mathrm{mL} / \mathrm{kg})\end{array}$ & $7.8[6.8-8.8]$ & $7.6[6.7-8.3]$ & $7.9[6.9-9.4]$ & 0.0095 \\
\hline Clinical PEEP $\left(\mathrm{cmH}_{2} \mathrm{O}\right)$ & $10[10-12]$ & 10 [10-12] & $10[10-12]$ & 0.24 \\
\hline Minute ventilation $\left(\mathrm{L} \mathrm{min}^{-1}\right)$ & $8.5[7.2-10.2]$ & $9.0[7.6-11-6]$ & $8.2[6.8-9.7]$ & 0.001 \\
\hline $\begin{array}{l}\text { Respiratory system compliance } \\
\left(\mathrm{mL} \mathrm{CmH}_{2} \mathrm{O}^{-1}\right)\end{array}$ & $38[32-50]$ & $37[30-45]$ & $41[33-51]$ & 0.11 \\
\hline
\end{tabular}

Student's $t$ test or Mann-Whitney rank sum test, as appropriate, were used to analyze continuous variables and the chi-square or Fisher's exact test, as appropriate, for non-continuous variables. Data are expressed as mean (standard deviation) or median [I.Q. range] as appropriate $N$ sample size, $y r$ years, $B M I$ body mass index, ARDS acute respiratory distress syndrome, SAPS Simplified Acute Physiology Score Italics: for all the statistical data

Bold italics: for statistical significant data

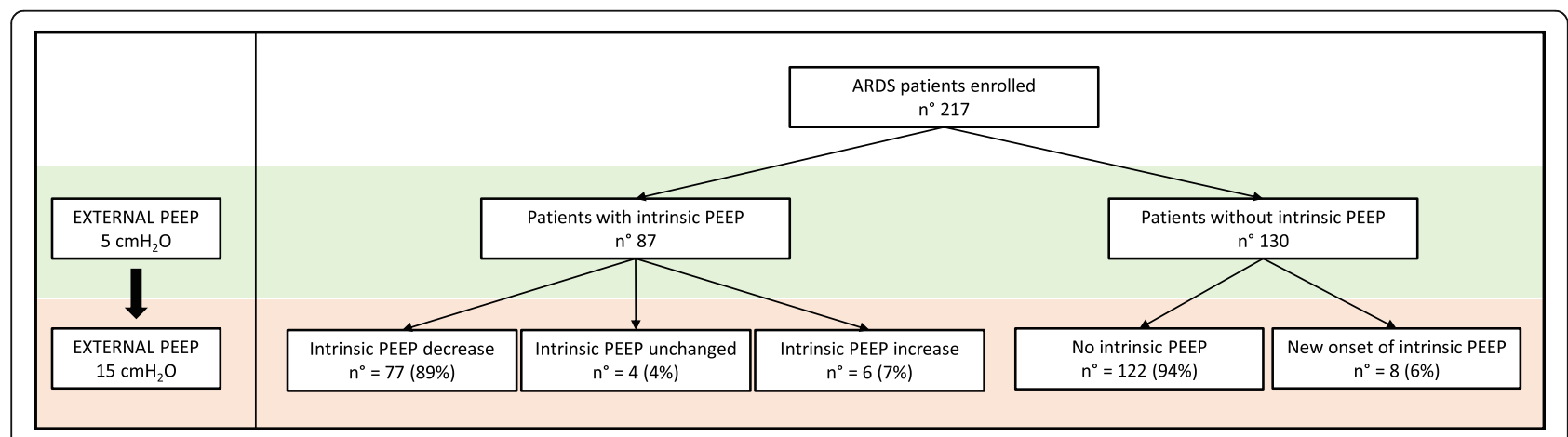

Fig. 1 The effect of external PEEP in patients with and without intrinsic PEEP 
Table 2 Respiratory mechanics at different PEEP in patients with and without intrinsic PEEP

\begin{tabular}{|c|c|c|c|c|c|}
\hline Parameter & Patients with intrinsic PEEP $(n=87)$ & Patients without intrinsic PEEP $(n=130)$ & $P_{\text {PEEPi }}$ & $P_{\text {PEEP }}$ & $P_{\text {PEEPIX PEEP }}$ \\
\hline \multicolumn{3}{|c|}{ Tidal volume (mL) } & 0.012 & 0.357 & 0.874 \\
\hline $5 \mathrm{cmH}_{2} \mathrm{O}$ & $480[430-540]$ & $520[445-600]$ & & & \\
\hline $15 \mathrm{cmH}_{2} \mathrm{O}$ & $480[430-540]$ & $510[430-590]$ & & & \\
\hline \multicolumn{3}{|c|}{ Respiratory rate (breath/min) } & $<0.001$ & 0.992 & 0.954 \\
\hline $5 \mathrm{cmH}_{2} \mathrm{O}$ & 18 [15-20] & 15 [13-19] & & & \\
\hline $15 \mathrm{cmH}_{2} \mathrm{O}$ & 18 [15-20] & 15 [13-19] & & & \\
\hline \multicolumn{3}{|c|}{ Minute ventilation (L/min) } & 0.007 & 0.559 & $0.048^{\wedge}$ \\
\hline $5 \mathrm{cmH}_{2} \mathrm{O}$ & $8.6[7.6-10.2]$ & $8.0[6.9-9.4]$ & & & \\
\hline $15 \mathrm{cmH}_{2} \mathrm{O}$ & $8.6[7.3-10.7]$ & $7.9[6.8-9.4]$ & & & \\
\hline \multicolumn{3}{|c|}{ Plateau pressure $\left(\mathrm{cmH}_{2} \mathrm{O}\right)$} & 0.726 & $<0.001$ & 0.061 \\
\hline $5 \mathrm{cmH}_{2} \mathrm{O}$ & $18.4[16.3-21.4]$ & $18.0[15.5-20.2]$ & & & \\
\hline $15 \mathrm{cmH}_{2} \mathrm{O}$ & $27.8[24.9-30.0]$ & $28.0[25.4-30.0]$ & & & \\
\hline \multicolumn{3}{|c|}{ Expiratory time (s) } & 0.002 & 0.884 & 0.774 \\
\hline $5 \mathrm{cmH}_{2} \mathrm{O}$ & $2.36[1.99-2.93]$ & $2.80[2.12-3.43]$ & & & \\
\hline $15 \mathrm{cmH}_{2} \mathrm{O}$ & 2.31 [1.92-2.92] & $2.80[2.12-3.40]$ & & & \\
\hline \multicolumn{3}{|c|}{ Total resistance $\left(\mathrm{cmH}_{2} \mathrm{O} \mathrm{s} \mathrm{L}{ }^{-1}\right)$} & 0.246 & 0.679 & 0.286 \\
\hline $5 \mathrm{cmH}_{2} \mathrm{O}$ & 13 [11-20] & 14 [11-18] & & & \\
\hline $15 \mathrm{cmH}_{2} \mathrm{O}$ & 13 [10-18] & 15 [12-19] & & & \\
\hline \multicolumn{3}{|c|}{ Respiratory system compliance $\left(\mathrm{mL} \mathrm{cmH}_{2} \mathrm{O}^{-1}\right)$} & 0.170 & 0.023 & 0.698 \\
\hline $5 \mathrm{cmH}_{2} \mathrm{O}$ & 43 [34-53] & $41[31-52]$ & & & \\
\hline $15 \mathrm{cmH}_{2} \mathrm{O}$ & 41 [30-51] & 38 [33-49] & & & \\
\hline \multicolumn{3}{|c|}{ Lung compliance $\left(\mathrm{mL} \mathrm{cmH}_{2} \mathrm{O}^{-1}\right)$} & 0.004 & 0.088 & 0.250 \\
\hline $5 \mathrm{cmH}_{2} \mathrm{O}$ & 57 [44-78] & $57[43-71]$ & & & \\
\hline $15 \mathrm{cmH}_{2} \mathrm{O}$ & 57 [44-72] & $54[41-66]$ & & & \\
\hline \multicolumn{3}{|c|}{ Chest wall compliance $\left(\mathrm{mL} \mathrm{cmH}_{2} \mathrm{O}^{-1}\right)$} & 0.981 & 0.564 & 0.388 \\
\hline $5 \mathrm{cmH}_{2} \mathrm{O}$ & 174 [125-272] & 178 [116-269] & & & \\
\hline $15 \mathrm{cmH}_{2} \mathrm{O}$ & 160 [103-272] & 158 [111-238] & & & \\
\hline \multicolumn{3}{|c|}{ Time constant (s) } & 0.192 & 0.549 & 0.554 \\
\hline $5 \mathrm{cmH}_{2} \mathrm{O}$ & $0.65[0.43-0.79]$ & $0.63[0.45-1.00]$ & & & \\
\hline $15 \mathrm{cmH}_{2} \mathrm{O}$ & $0.56[0.36-0.77]$ & $0.57[0.44-0.73]$ & & & \\
\hline
\end{tabular}

Data are expressed as median [I.Q. range] as appropriate

Two-way repeated measures analysis of variance (ANOVA) followed by all pairwise multiple comparison procedures (Holm-Sidak method) were used for analysis $n$ sample size, PEEP positive-end expiratory pressure

$\hat{A}$ < 0.05 : minute ventilation is higher in patients with intrinsic PEEP than those without intrinsic PEEP at PEEP 15. There are no other significant interactions Italics: for all the statistical data

Bold italics: for statistical significant data

\section{Computer tomography}

Table 3 shows the CT data at 5 and $45 \mathrm{cmH}_{2} \mathrm{O}$ of airway pressure. The total lung gas volume was no different in the two groups at the two pressures. In both groups, the percentages of not inflated and poorly inflated tissue were similarly reduced while the well-inflated tissue increased from 5 to $45 \mathrm{cmH}_{2} \mathrm{O}$ of airway pressure.

\section{Lung recruitability and gas exchange}

Lung recruitability was not different among patients with and without intrinsic PEEP (15 [0-32] \% vs 22 [0-36] \%).
Pulmonary gas exchange data are presented in Table 4. $\mathrm{PaO}_{2}$ was similar between patients with and without intrinsic PEEP at $5 \mathrm{cmH}_{2} \mathrm{O}$ (71 [64-83] $\mathrm{mmHg}$ vs 73 [63-93]) and similarly increased at $15 \mathrm{cmH}_{2} \mathrm{O}(94$ [75-124] $\mathrm{mmHg}$ vs 99 [80-123] mmHg). $\mathrm{PaCO}_{2}$ and physiological and alveolar dead space did not differ between the two groups (Table 4 and Additional file 1: Table S2).

\section{Discussion}

In this population of ARDS patients evaluated in the early phase of the disease, (1) intrinsic PEEP was 
Table 3 Computed tomography data in patients with and without intrinsic PEEP

\begin{tabular}{|c|c|c|c|c|c|}
\hline & Patients with intrinsic PEEP $(n=87)$ & Patients without intrinsic PEEP $(n=130)$ & $P_{\text {PEEPi }}$ & $P_{\text {PEEP }}$ & $P_{\text {PEEPIX PEEP }}$ \\
\hline \multicolumn{3}{|c|}{ Total weight (g) } & 0.72 & N.A. & N.A. \\
\hline $5 \mathrm{cmH}_{2} \mathrm{O}$ & $1366[1151-1666]$ & $1411[1172-1674]$ & & & \\
\hline \multicolumn{3}{|c|}{ Total gas volume $(\mathrm{mL})$} & 0.79 & N.A. & N.A. \\
\hline $5 \mathrm{cmH}_{2} \mathrm{O}$ & $961[701-1535]$ & 973 [659-1433] & & & \\
\hline \multicolumn{3}{|c|}{ Non-inflated tissue (\%) } & 0.242 & $<0.001$ & 0.301 \\
\hline $5 \mathrm{cmH}_{2} \mathrm{O}$ & $39[26-53]$ & $43[33-55]$ & & & \\
\hline $45 \mathrm{cmH}_{2} \mathrm{O}$ & 25 [18-35] & 27 [15-38] & & & \\
\hline \multicolumn{3}{|c|}{ Poorly inflated tissue (\%) } & 0.815 & $<0.001$ & 0.490 \\
\hline $5 \mathrm{cmH}_{2} \mathrm{O}$ & 30 [23-39] & $28[21-40]$ & & & \\
\hline $45 \mathrm{cmH}_{2} \mathrm{O}$ & 21 [18-33] & 25 [19-35] & & & \\
\hline \multicolumn{3}{|c|}{ Well-inflated tissue (\%) } & 0.203 & $<0.001$ & 0.888 \\
\hline $5 \mathrm{cmH}_{2} \mathrm{O}$ & $26[15-40]$ & 25 [14-34] & & & \\
\hline $45 \mathrm{cmH}_{2} \mathrm{O}$ & $43[37-56]$ & $43[34-55]$ & & & \\
\hline \multicolumn{3}{|c|}{ Over-inflated tissue (\%) } & 0.814 & $<0.001$ & 0.149 \\
\hline $5 \mathrm{cmH}_{2} \mathrm{O}$ & $0.01[0-0.13]$ & $0.01[0-0.11]$ & & & \\
\hline $45 \mathrm{cmH}_{2} \mathrm{O}$ & $0.7[0.21-4.17]$ & $1.49[0.36-4.60]$ & & & \\
\hline
\end{tabular}

Data are expressed as median [I.Q. range] as appropriate

Two-way repeated measures analysis of variance (ANOVA) followed by all pairwise multiple comparison procedures (Holm-Sidak method) was used for analysis $p<0.05$ raising airway pressure from 5 to $45 \mathrm{cmH}_{2} \mathrm{O}$

There are no significant interactions

$n$ sample size, PEEP positive end-expiratory pressure

Italics: for all the statistical data

Bold italics: for statistical significant data

Table 4 Gas exchange at different levels of PEEP in patients with and without intrinsic PEEP

\begin{tabular}{|c|c|c|c|c|c|}
\hline Parameter & Patients with intrinsic PEEP $(n=87)$ & Patients without intrinsic PEEP $(n=130)$ & $P_{\text {PEEPi }}$ & $P_{\text {PEEP }}$ & $P_{\text {PEEPIX PEEP }}$ \\
\hline \multicolumn{3}{|l|}{$\mathrm{PaO}_{2}(\mathrm{mmHg})$} & 0.761 & $<0.001$ & 0.939 \\
\hline $5 \mathrm{cmH}_{2} \mathrm{O}$ & $71[64-83]$ & 73 [63-93] & & & \\
\hline $15 \mathrm{cmH}_{2} \mathrm{O}$ & $94[75-124]$ & 99 [80-123] & & & \\
\hline \multicolumn{3}{|l|}{$\mathrm{PaO}_{2} / \mathrm{FiO}_{2}$} & 0.118 & $<0.001$ & 0.957 \\
\hline $5 \mathrm{cmH}_{2} \mathrm{O}$ & 138 [100-183] & 151 [119-185] & & & \\
\hline $15 \mathrm{cmH}_{2} \mathrm{O}$ & 194 [144-252] & 200 [159-259] & & & \\
\hline \multicolumn{3}{|l|}{$\mathrm{PaCO}_{2}(\mathrm{mmHg})$} & 0.111 & 0.518 & 0.787 \\
\hline $5 \mathrm{cmH}_{2} \mathrm{O}$ & $44[40-52]$ & $44[38-51]$ & & & \\
\hline $15 \mathrm{cmH}_{2} \mathrm{O}$ & $44[41-52]$ & $38[22-42]$ & & & \\
\hline \multicolumn{3}{|c|}{ Alveolar dead space (\%) } & 0.279 & 0.345 & 0.425 \\
\hline $5 \mathrm{cmH}_{2} \mathrm{O}$ & $20[12-26]$ & $23[13-30]$ & & & \\
\hline $15 \mathrm{cmH}_{2} \mathrm{O}$ & 19 [13-27] & $21[11-29]$ & & & \\
\hline \multicolumn{3}{|c|}{ Alveolar dead space $(\mathrm{mL})$} & 0.186 & 0.010 & 0.107 \\
\hline $5 \mathrm{cmH}_{2} \mathrm{O}$ & $105[66-137]$ & $111[74-153]$ & & & \\
\hline $15 \mathrm{cmH}_{2} \mathrm{O}$ & $98[68-131]$ & 105 [62-140] & & & \\
\hline
\end{tabular}

Data are expressed as median [I.Q. range] as appropriate

Two-way repeated measures analysis of variance (ANOVA) followed by all pairwise multiple comparison procedures (Holm-Sidak method) was used for analysis $p<0.05$ raising end-expiratory pressure from 5 to $15 \mathrm{cmH}_{2} \mathrm{O}$

There are no significant interactions

$n$ sample size, PEEP positive end-expiratory pressure

Italics: for all the statistical data

Bold italics: for statistical significant data 
detected in 40\%, with a median of 1.1 [1.0-2.3] $\mathrm{cmH}_{2} \mathrm{O}$ at $5 \mathrm{cmH}_{2} \mathrm{O}$ of PEEP; (2) patients with intrinsic PEEP had a ventilatory setting with a lower tidal volume and higher respiratory rate, higher lung compliance, and similar time constant, lung gas volume, and gas exchange compared to patients without intrinsic PEEP; and (3) when the external PEEP was raised from 5 to $15 \mathrm{cmH}_{2} \mathrm{O}$, intrinsic PEEP decreased significantly.

The first descriptions of dynamic hyperinflation and intrinsic PEEP in COPD patients were reported by Pepe and Marini [3]. In the presumed pathophysiological mechanism is the failure for the lung units to empty their volume and to reach their relaxation volume before a new inspiration is initiated, mainly due to the expiratory flow limitated by airway collapse [3, 4, 10, 32, 33].

In ARDS patients, dynamic hyperinflation and intrinsic PEEP can be generated by the expiratory flow limitation and by the combination of short expiratory time and high respiratory rate when the lungs do not have enough time to reach their equilibrium volume during passive deflation [2, 4, 32, 34]. Dynamic hyperinflation and intrinsic PEEP can have several negative effects on the respiratory system and on hemodynamics. They may increase the work of breathing and the lung gas volume and reduce the preload and cardiac output $[3,16]$.

At the bedside, intrinsic PEEP can be suspected whenever the expiratory gas flow is abruptly interrupted by the next inflation of the ventilator. In mechanically ventilated patients, dynamic hyperinflation can be quantified as the amount of intrinsic PEEP computed as a positive pressure higher than the PEEP set on the ventilator during a prolonged expiratory pause in the absence of any expiratory flow limitation. Otherwise dynamic hyperinflation can be quantified as the amount of total PEEP not explained by the external PEEP set on the ventilator: this may happen when an increase in the external PEEP does not cause a proportional increase in the total PEEP, when there is a limitation of expiratory flow. This method is accurate only when patients are well sedated with or without paralysis [3, 4, 32, 33]. The ARDS patients in the present study were sedated and paralyzed. They were ventilated with low tidal volume and a clinical, not preselected, respiratory rate and expiratory time to avoid respiratory acidosis, reflecting a common ventilatory strategy of ARDS patients in intensive care [35].

\section{Respiratory mechanics and body mass index}

Regarding respiratory mechanics, only lung compliance was significantly different but not to any clinically relevant extent. In patients without muscle activity, deflation of the respiratory system is completely passive and the entire force for exhalation derives from the elastic potential energy stored in the respiratory system during the inspiration [36]. Taking into account the equation of motion of the respiratory system, the time required for complete exhalation depends on the product of total resistance and compliance, which is the time constant of the respiratory system [37]. Assuming a homogeneous lung compartment model with only one time constant, where the expiratory time equals the product of resistance for compliance, the volume that will remain in the respiratory system should be approximately $37 \%$ of the inspired volume [36]. Three time constants are required to reach a $95 \%$ volume exhalation $[38,39]$. Thus, for a given applied tidal volume, if there is a significant increase in compliance or resistance, it will take longer to reach the resting volume. ARDS patients, characterized by reduced compliance [1], should be theoretically protected from developing dynamic hyperinflation $[28,39]$.

On the other hand, an increase in resistance can promote the development of dynamic hyperinflation. In the present study, the product of compliance and resistance was not different (i.e., time constant) in the two groups, suggesting the respiratory mechanics have no role in promoting intrinsic PEEP.

Morbidly obese patients compared with normal-weight patients, especially in a supine position and during general anesthesia, can present a combination of factors, such as expiratory flow limitation and a larger amount of peripheral airway closure volume [40, 41], that can result in intrinsic PEEP. Grieco et al., with a low-flow P-V curve technique, showed that $22 \%$ of obese patients under general anesthesia presented airway closure with a median airway opening pressure of $9 \mathrm{cmH}_{2} \mathrm{O}$ [42]

Similar data were reported in ARDS patients by Yonis et al. who found a significantly higher airway opening pressure in patients with a higher body mass index [18].

As expected, in the present study, the patients with intrinsic PEEP had a significantly higher body mass index, even if lower than $30 \mathrm{~kg} / \mathrm{m}^{2}$, than patients without intrinsic PEEP. However, since in the present study we did not have a P-V curve loop, we could not assess the possible presence of airway closure which has been reported between 25 and $50 \%$ of ARDS patients [17, 19].

\section{Ventilatory settings}

In mechanically ventilated patients, the increased expiratory airway resistance caused by the endotracheal tube and by the expiratory valve of the mechanical ventilator can promote dynamic hyperinflation [43]. In this study, although we did not record the sizes of the endotracheal tubes employed, we can assume there were no differences between the two groups because the percentages of males and females were similar. Our policy is to use larger endotracheal tubes in males than in females.

As regards the expiratory valve, we did not use the same mechanical ventilators in all patients; however, our latest-generation intensive care mechanical ventilators 
are able to limit any expiratory resistance as much as possible.

Under passive conditions, the short expiratory time, the high respiratory rate, and the minute ventilation promote dynamic hyperinflation [2, 44]. In ARDS patients, low tidal volume, which reduces stress and strain, is widely recommended in order to reduce ventilator-induced lung injury (VILI) [35]. However, to avoid respiratory acidosis, the respiratory rate is commonly raised to maintain adequate minute ventilation and carbon dioxide clearance. Richard et al. found that raising the respiratory rate from 17 to 30 breaths/min significantly increased intrinsic PEEP, from 1.3 to $3.9 \mathrm{cmH}_{2} \mathrm{O}$, maintaining the same low tidal volume ( $6 \mathrm{~mL} / \mathrm{kg}$ of predicted body weight) [14]. However, in our study, the respiratory rate and minute ventilation were increased simultaneously, and they can promote dynamic hyperinflation [44], although our intrinsic PEEP was lower. For a similar minute ventilation $(12 \mathrm{~L} / \mathrm{min})$, obtained with a different combination of low/high tidal volume and low/high respiratory rate, De Durante et al. found a progressive increase in intrinsic PEEP from 1.4 to $5.8 \mathrm{cmH}_{2} \mathrm{O}$ with an increase in respiratory rate from 14 to 34 breaths/min [15].

In line with previous data, we found that patients with intrinsic PEEP were ventilated with higher respiratory rate and lower expiratory time than those without. Furthermore, the amount of intrinsic PEEP found in our study should approximately correspond to what was reported by Richard et al. for similar respiratory rates [14].

\section{PEEP response}

Whenever an external PEEP is changed, the resulting new intrinsic PEEP is computed as the difference between the total PEEP measured during an expiratory pause and the applied by the ventilator [5, 28]. In ARDS patients, the PEEP is commonly used not only to improve gas exchange [45] but also to reduce lung inhomogeneity [20] and optimize recruitability [46, 47]. In a mixed population of COPD patients and patients with acute respiratory failure, when there was expiratory flow limitation, the higher external PEEP significantly reduced the intrinsic PEEP, which was "absorbed" in the total PEEP. In contrast, in patients without expiratory flow limitation, the intrinsic PEEP did not change and the total PEEP could be increased [12, 48].

Many studies have proposed raising the PEEP to detect any expiratory flow limitation: an external PEEP higher than the intrinsic PEEP can reduce the expiratory flow on the flow-volume loop $[49,50]$. In the present study, on raising the applied PEEP from 5 to $15 \mathrm{cmH}_{2} \mathrm{O}$, intrinsic PEEP was significantly reduced in $89 \%$ of the patients and increased only in 4\%; this might be due to airway closure and flow limitation at PEEP 5 and an airway opening pressure between 5 and $15 \mathrm{cmH}_{2} \mathrm{O}$ that absorbs intrinsic PEEP. However, this value is clinically not important, suggesting expiratory flow limitation has no substantial role. In addition, the response in oxygenation was no different among patients with or without intrinsic PEEP. In fact, as Koutsoukou et al. showed arterial oxygenation significantly increased with the rise in external PEEP independently from the amount of intrinsic PEEP [12].

The two groups presented similar amounts of not consolidated tissue, lung gas volume, and lung recruitability, while the $\mathrm{PaO}_{2} / \mathrm{FiO}_{2}$ ratio was worse and the mortality rate was slightly higher in patients with intrinsic PEEP. Although in ARDS patients $\mathrm{PaO}_{2} / \mathrm{FiO}_{2}$ is commonly used in clinical practice to assess the severity and the response to ventilation and therapy, it is not a "research" indicator of the impairment of oxygenation (i.e., alveolar shunt). In fact, several extrapulmonary factors such as the concentration of hemoglobin, cardiac output, and the arterial-venous oxygen content can significantly affect $\mathrm{PaO}_{2} / \mathrm{FiO}_{2}$, independently from the severity of lung disease.

\section{Limitations}

Limitations of this study are as follows: (1) the absence of data on airway resistance, because we only computed the total resistance including the endotracheal tubes; (2) the absence of any diagnosis of the expiratory flow limitation on the flow-volume loop or measuring the endexpiratory lung volume; and (3) the lack of measurements of intrinsic PEEP at zero PEEP.

\section{Conclusions}

In conclusion, in sedated, paralyzed ARDS patients without a known obstructive disease, the amount of intrinsic PEEP during lung-protective ventilation is negligible and does not influence gas exchange or the respiratory mechanics in terms of response to external PEEP and lung recruitability.

\section{Supplementary information}

Supplementary information accompanies this paper at https://doi.org/10. 1186/s13054-019-2611-6.

Additional file 1. Calculations of physiological variables: formulas used to calculate all physiological variables; Respiratory mechanics variables: data about driving pressure, transpulmonary driving pressure, elastance-derived transpulmonary pressure and end-expiratory transpulmonary pressure; Dead space: data about alveolar, physiological and anatomic dead space expressed both as volume and percentage; Comparison between Tidal Volume and Respiratory Rate in patients with and without intrinsic PEEP: boxplots describe the comparison between Tidal Volume in patients with and without intrinsic PEEP at $5 \mathrm{CmH}_{2} \mathrm{O}$ on the left panel; the comparison between Respiratory Rate in patients with and without intrinsic PEEP at 5 $\mathrm{CmH}_{2} \mathrm{O}$ on the right panel.

\section{Abbreviations}

ARDS: Acute respiratory distress syndrome; $C_{c w}$ : Chest wall compliance; $C_{L}$ : Lung compliance; COPD: Chronic obstructive pulmonary disease; 
$C_{\text {RS }}$ : Respiratory system compliance; CT: Computed tomography; DP: Driving pressure; PEEP: Positive end-expiratory pressure; $P_{\text {Plat }}$ : Plateau pressure, endinspiratory airway pressure at end-inspiratory pause; $R_{\max }$, rs: Total resistance; VILI: Ventilator-induced lung injury; Vt: Tidal volume

\section{Authors' contributions}

DC and SC were responsible for the study concept and design. DC, AC, and SF were responsible for the data analysis and interpretation. SC, AC, SF, EF, $P F, M G$, and DC were responsible for the critical revision of the manuscript. All authors read and approved the final manuscript.

\section{Funding}

Not applicable

\section{Availability of data and materials}

The datasets used and analyzed in the study are available from the corresponding author on reasonable request.

\section{Ethics approval and consent to participate}

The datasets used for the current study came from seven published studies. The institutional review board of each hospital (Ethics Committee Milan, zones 1 and 2) approved each study, and written consent was obtained according to the regulations applied in each Institution.

\section{Consent for publication}

Not applicable

\section{Competing interests}

The authors declare that they have no competing interests.

\section{Author details}

'Department of Anesthesia and Intensive Care, ASST Santi Paolo e Carlo, San Paolo University Hospital, Milan, Italy. ${ }^{2}$ Department of Health Sciences, University of Milan, Milan, Italy. ${ }^{3}$ Coordinated Research Center on Respiratory Failure, University of Milan, Milan, Italy. ${ }^{4}$ SC Anestesia e Rianimazione, ASST Santi Paolo e Carlo, Via Di Rudini, Milan, Italy.

Received: 1 May 2019 Accepted: 13 September 2019

Published online: 27 November 2019

\section{References}

1. Pelosi P, Cereda M, Foti G, Giacomini M, Pesenti A. Alterations of lung and chest wall mechanics in patients with acute lung injury: effects of positive end-expiratory pressure. Am J Respir Crit Care Med. 1995;152(2):531-7.

2. Marini JJ. Dynamic hyperinflation and auto-positive end-expiratory pressure Am J Respir Crit Care Med. 2011;184(7):756-62.

3. Pepe PE, Marini JJ. Occult positive end-expiratory pressure in mechanically ventilated patients with airflow obstruction: the auto-PEEP effect. Am Rev Respir Dis. 1982;126(1):166-70.

4. Rossi A, Gottfried SB, Zocchi L, Higgs BD, Lennox S, Calverley PM, et al Measurement of static compliance of the total respiratory system in patients with acute respiratory failure during mechanical ventilation. The effect of intrinsic positive end-expiratory pressure. Am Rev Respir Dis. 1985; 131(5):672-7.

5. Junhasavasdikul D, Telias I, Grieco DL, Chen L, Gutierrez CM, Piraino T, et al. Expiratory flow limitation during mechanical ventilation. Chest. 2018;154(4): 948-62

6. Valta P, Corbeil C, Lavoie A, Campodonico R, Koulouris N, Chassé M, et al. Detection of expiratory flow limitation during mechanical ventilation. Am J Respir Crit Care Med. 1994;150(5 Pt 1):1311-7.

7. Gottfried SB. The role of PEEP in the mechanically ventilated COPD patient. Heidelberg: Springer; 1991. p. 392-418

8. Eltayara L, Becklake MR, Volta CA, Milic-Emili J. Relationship between chronic dyspnea and expiratory flow limitation in patients with chronic obstructive pulmonary disease. Am J Respir Crit Care Med. 1996;154(6):1726-34.

9. Koulouris NG, Dimopoulou I, Valta P, Finkelstein R, Cosio MG, Milic-Emili J. Detection of expiratory flow limitation during exercise in COPD patients. J Appl Physiol. 1997;82(3):723-31.

10. Broseghini C, Brandolese R, Poggi R, Polese G, Manzin E, Milic-Emili J, et al. Respiratory mechanics during the first day of mechanical ventilation in patients with pulmonary edema and chronic airway obstruction. Am Rev Respir Dis. 1988;138(2):355-61.

11. Koutsoukou A, Armaganidis A, Stavrakaki-Kallergi C, Vassilakopoulos T, Lymberis A, Roussos C, et al. Expiratory flow limitation and intrinsic positive end-expiratory pressure at zero positive end-expiratory pressure in patients with adult respiratory distress syndrome. Am J Respir Crit Care Med. 2000; 161(5):1590-6.

12. Koutsoukou A, Bekos B, Sotiropoulou C, Koulouris NG, Roussos C, Milic-Emili J. Effects of positive end-expiratory pressure on gas exchange and expiratory flow limitation in adult respiratory distress syndrome. Crit Care Med. 2002:30(9):1941-9.

13. Rodarte JR, Hyatt RE, Cortese DA. Influence of expiratory flow on closing capacity at low expiratory flow rates. J Appl Physiol. 1975;39(1):60-5.

14. Richard J-C, Brochard L, Breton L, Aboab J, Vandelet P, Tamion F, et al. Influence of respiratory rate on gas trapping during low volume ventilation of patients with acute lung injury. Intensive Care Med. 2002;28(8):1078-83.

15. de Durante G, del Turco M, Rustichini L, Cosimini P, Giunta F, Hudson LD, et al. ARDSNet lower tidal volume ventilatory strategy may generate intrinsic positive end-expiratory pressure in patients with acute respiratory distress syndrome. Am J Respir Crit Care Med. 2002;165(9):1271-4.

16. Vieillard-Baron A, Prin S, Augarde R, Desfonds P, Page B, Beauchet A, et al. Increasing respiratory rate to improve $\mathrm{CO} 2$ clearance during mechanical ventilation is not a panacea in acute respiratory failure. Crit Care Med. 2002; 30(7):1407-12

17. Chen L, Del Sorbo L, Grieco DL, Shklar O, Junhasavasdikul D, Telias I, et al. Airway closure in acute respiratory distress syndrome: an underestimated and misinterpreted phenomenon. Am J Respir Crit Care Med. 2018;197(1):132-6.

18. Yonis H, Mortaza S, Baboi L, Mercat A, Guérin C. Expiratory flow limitation assessment in patients with acute respiratory distress syndrome. A reappraisal. Am J Respir Crit Care Med. 2018;198(1):131-4.

19. Coudroy R, Lu C, Chen L, Demoule A, Brochard L. Mechanism of airway closure in acute respiratory distress syndrome: a possible role of surfactant depletion. Intensive Care Med. 2019:45(2):290-1.

20. Cressoni M, Chiumello D, Chiurazzi C, Brioni M, Algieri I, Gotti M, et al. Lung inhomogeneities, inflation and [18F]2-fluoro-2-deoxy-D-glucose uptake rate in acute respiratory distress syndrome. Eur Respir J. 2016;47(1):233-42.

21. Gattinoni L, Caironi P, Cressoni M, Chiumello D, Ranieri VM, Quintel M, et al. Lung recruitment in patients with the acute respiratory distress syndrome. N Engl J Med. 2006;354(17):1775-86.

22. Cressoni M, Chiumello D, Algieri I, Brioni M, Chiurazzi C, Colombo A, et al. Opening pressures and atelectrauma in acute respiratory distress syndrome. Intensive Care Med. 2017:43(5):603-11.

23. Chiumello D, Cressoni M, Carlesso E, Caspani ML, Marino A, Gallazzi E, et al. Bedside selection of positive end-expiratory pressure in mild, moderate, and severe acute respiratory distress syndrome* ${ }^{*}$ Crit Care Med. 2014:42(2):252-64.

24. Chiumello D, Marino A, Brioni M, Cigada I, Menga F, Colombo A, et al. Lung recruitment assessed by respiratory mechanics and computed tomography in patients with acute respiratory distress syndrome. What is the relationship? Am J Respir Crit Care Med. 2016;193(11):1254-63.

25. Chiumello D, Mongodi S, Algieri I, Vergani GL, Orlando A, Via G, et al. Assessment of lung aeration and recruitment by $C T$ scan and ultrasound in acute respiratory distress syndrome patients*. Crit Care Med. 2018;46(11):1761-8.

26. Chiumello D, Marino A, Cressoni M, Mietto C, Berto V, Gallazzi E, et al. Pleural effusion in patients with acute lung injury: a CT scan study. Crit Care Med. 2013:41(4):935-44.

27. Ferguson ND, Fan E, Camporota L, Antonelli M, Anzueto A, Beale R, et al. The Berlin definition of ARDS: an expanded rationale, justification, and supplementary material. Intensive Care Med. 2012:38(10):1573-82.

28. Ranieri VM, Eissa NT, Corbeil C, Chassé M, Braidy J, Matar N, et al. Effects of positive end-expiratory pressure on alveolar recruitment and gas exchange in patients with the adult respiratory distress syndrome. Am Rev Respir Dis. 1991;144(3_pt_1):544-51.

29. Akoumianaki E, Maggiore SM, Valenza F, Bellani G, Jubran A, Loring SH, et al. The application of esophageal pressure measurement in patients with respiratory failure. Am J Respir Crit Care Med. 2014;189(5):520-31.

30. Bohr C. Ueber die Lungenathmung'. Skand Arch Physiol. 1891;2(1):236-68.

31. Gattinoni L, Caironi P, Pelosi P, Goodman LR. What has computed tomography taught us about the acute respiratory distress syndrome? Am J Respir Crit Care Med. 2001;164(9):1701-11. 
32. Ranieri VM, Grasso S, Fiore T, Giuliani R. Auto-positive end-expiratory pressure and dynamic hyperinflation. Clin Chest Med. 1996;17(3):379-94.

33. Gottfried SB, Rossi A, Higgs BD, Calverley PM, Zocchi L, Bozic C, et al. Noninvasive determination of respiratory system mechanics during mechanical ventilation for acute respiratory failure. Am Rev Respir Dis. 1985; 131(3):414-20.

34. Tuxen DV, Lane $\mathrm{S}$. The effects of ventilatory pattern on hyperinflation, airway pressures, and circulation in mechanical ventilation of patients with severe air-flow obstruction. Am Rev Respir Dis. 1987;136(4):872-9.

35. Chiumello D, Brochard L, Marini JJ, Slutsky AS, Mancebo J, Ranieri VM, et al. Respiratory support in patients with acute respiratory distress syndrome: an expert opinion. Crit Care. 2017;21(1):240

36. Bergman NA. Intrapulmonary gas trapping during mechanical ventilation at rapid frequencies. Anesthesiology. 1972;37(6):626-33.

37. Bergman NA. Measurement of respiratory resistance in anesthetized subjects. J Appl Physiol. 1966;21(6):1913-7.

38. Lumb AB, Nunn JF. Nunn's applied respiratory physiology. Elsevier Butterworth Heinemann; 2005. 501 p.

39. Vieillard-Baron A, Jardin F. The issue of dynamic hyperinflation in acute respiratory distress syndrome patients. Eur Respir J Suppl. 2003;42:43s-7s.

40. Koutsoukou A, Koulouris N, Bekos B, Sotiropoulou C, Kosmas E, Papadima K, et al. Expiratory flow limitation in morbidly obese postoperative mechanically ventilated patients. Acta Anaesthesiol Scand. 2004;48(9):1080-8

41. Pankow W, Podszus T, Gutheil T, Penzel T, Peter J, Von Wichert P. Expiratory flow limitation and intrinsic positive end-expiratory pressure in obesity. J Appl Physiol. 1998;85(4):1236-43.

42. Grieco DL, Anzellotti GM, Russo A, Bongiovanni F, Costantini B, D'Indinosante $\mathrm{M}$, et al. Airway closure during surgical pneumoperitoneum in obese patients. Anesthesiology. 2019;131(1):58-73.

43. Marini JJ. Should PEEP be used in airflow obstruction? Am Rev Respir Dis. 1989;140(1):1-3.

44. Marini JJ, Crooke PS. A general mathematical model for respiratory dynamics relevant to the clinical setting. Am Rev Respir Dis. 1993;147(1):14-24.

45. Suter PM, Fairley HB, Isenberg MD. Optimum end-expiratory airway pressure in patients with acute pulmonary failure. N Engl J Med. 1975;292(6):284-9.

46. Gattinoni L, Pelosi P, Crotti S, Valenza F. Effects of positive end-expiratory pressure on regional distribution of tidal volume and recruitment in adult respiratory distress syndrome. Am J Respir Crit Care Med. 1995;151(6):1807-14.

47. Caironi P, Cressoni M, Chiumello D, Ranieri M, Quintel M, Russo SG, et al. Lung opening and closing during ventilation of acute respiratory distress syndrome. Am J Respir Crit Care Med. 2010;181(6):578-86.

48. Natalini G, Tuzzo D, Rosano A, Testa M, Grazioli M, Pennestrì V, et al. Effect of external PEEP in patients under controlled mechanical ventilation with an auto-PEEP of $5 \mathrm{cmH} 2 \mathrm{O}$ or higher. Ann Intensive Care. 2016;6(1):53.

49. Kondili E, Alexopoulou C, Prinianakis G, Xirouchaki N, Georgopoulos D. Pattern of lung emptying and expiratory resistance in mechanically ventilated patients with chronic obstructive pulmonary disease. Intensive Care Med. 2004;30(7):1311-8.

50. Spadaro S, Caramori G, Rizzuto C, Mojoli F, Zani G, Ragazzi R, et al. Expiratory flow limitation as a risk factor for pulmonary complications after major abdominal surgery. Anesth Analg. 2017;124(2):524-30.

\section{Publisher's Note}

Springer Nature remains neutral with regard to jurisdictional claims in published maps and institutional affiliations.

Ready to submit your research? Choose BMC and benefit from:

- fast, convenient online submission

- thorough peer review by experienced researchers in your field

- rapid publication on acceptance

- support for research data, including large and complex data types

- gold Open Access which fosters wider collaboration and increased citations

- maximum visibility for your research: over $100 \mathrm{M}$ website views per year

At $\mathrm{BMC}$, research is always in progress.

Learn more biomedcentral.com/submissions 